\title{
Tingkat Daya Tahan Jantung Paru Pada Pusat Pendidikan dan Latihan Pelajar Atlet Sepak Bola (PPLP) Pekanbaru Menggunakan Metode Lari 12 Menit
}

\author{
Afandi Ahmad ${ }^{1 *}$, Miftah Azrin², Firdaus ${ }^{3}$
}

\begin{abstract}
Cardiorespiratory fitness is defined as the maximum capacity of the heart and lungs to inhale and spread oxygen or abbreviated as VO2 Max. The higher the VO2 max, the higher the body's resistance when exercising, so that an athlete is very important to have a high level of VO2 max. This research was a descriptive study with a sample of all Center for Education and Training soccer athletes measured using the 12-minute run method. Based on the research, the highest age was 15 years with a frequency of 9 (37.5\%), with the most practice time was those who practiced for $<1$ year with a frequency of $15(62.5 \%)$, most of the respondents have normal nutritional status with frequency 17 ( $70.8 \%)$, and the highest value of cardiorespiratory fitness (VO2 Max) is sufficient with a frequency of 17 athletes (70.8\%).
\end{abstract}

Keywords: Soccer,cardiorespiratory fitness, 12-minute run test, VO2 max

Pusat Pendidikan dan Latihan Pelajar (PPLP) merupakan sekolah pembibitan olahraga nasional, yang digunakan untuk mencari dan membina bakat olahraga pada usia sekolah. Setiap tahunnya diadakan kejuaraan nasional antar PPLP yang diselenggarakan Kementerian Pemuda dan Olahraga. Kegiatan ini adalah bagian dari sistem kompetisi olahraga pelajar secara nasional yang berjenjang dan berkelanjutan. Tujuan dari kejuaraan nasional antar PPLP adalah sebagai puncak pembinaan prestasi olahraga pelajar dan evaluasi terhadap berbagai bentuk pembinaan PPLP. Salah satu fokus cabang olahraga PPLP adalah sepakbola. ${ }^{1}$

Sepak bola merupakan olahraga yang paling populer di dunia dan bahkan telah menjadi olahraga nasional bagi setiap negara di Eropa, Amerika, Asia dan bahkan di Afrika. Sepak bola menjadi olahraga populer karena sepakbola merupakan olahraga yang

\footnotetext{
* Penulis untuk korespondensi : Email : 96afandiahmad @gmail.com

1 Program Studi Kedokteran Fakultas Kedokteran Universitas Riau, Pekanbaru, Riau

2 KJFD Fisiologi Fakultas Kedokteran Universitas Riau, Pekanbaru, Riau

3 KJFD Pendidikan Kedokteran Fakultas Kedokteran Universitas Riau, Pekanbaru, Riau
}

sangat digemari oleh semua kalangan baik untuk anak-anak, orang dewasa, bahkan orang tua. Sepak bola digemari oleh semua kalangan karena sepak bola merupakan olahraga yang murah dan dapat dilakukan oleh siapapun dan dimanapun seperti di lapangan berlumpur, tanah liat, sawah, jalan atau gang-gang sempit., ${ }^{2,4}$

Sepak bola adalah permainan menggunakan bola yang dimainkan oleh dua tim, masing-masing tim terdiri dari sebelas orang pemain termasuk seorang penjaga gawang. ${ }^{4}$ Sepak bola yang dilihat dari segi lamanya bermain merupakan bentuk olahraga yang berat, sepak bola dituntut untuk bergerak cepat secara terus menerus. Oleh karena itu pemain sepak bola harus sanggup bermain 2x45 menit, bahkan hingga babak tambahan selama 2x15 menit jika pertandingan memang memerlukan babak tambahan, dan pemain juga dituntut untuk memiliki kebugaran jasmani yang baik. ${ }^{5}$

Tingkat kebugaran jasmani akan sangat berpengaruh terhadap pencapaian prestasi terutama pada olahraga yang dituntut untuk bergerak cepat dan terus menerus seperti sepak bola. ${ }^{6}$ Kebugaran jasmani yang prima akan berdampak positif terhadap peningkatan kemampuan sirkulasi darah dan kerja jantung, peningkatan kekuatan, kelenturan, daya 
tahan, koordinasi, keseimbangan, kecepatan, dan kelincahan tubuh, selain itu akan berdampak pada terjadinya peningkatan kemampuan gerak secara eûsien dan peningkatan kemampuan pemulihan organ-organ tubuh setelah latihan serta meningkatnya kemampuan daya respons tubuh. Permainan sepakbola menuntut setiap pemain agar selalu bergerak cepat dan tepat untuk mencari ruang kosong, merebut bola, dan mencetak gol, sehingga para pemain sepakbola wajib memiliki kebugaran jasmani yang baik agar dapat mendukung pergerakan secara efisien dan efektif. ${ }^{7}$

Kebugaran jasmani merupakan suatu kemampuan tubuh seseorang dalam melakukan pekerjaan sehari-hari secara efektif dan efisien dalam jangka waktu relatif lama tanpa menimbulkan kelelahan yang berlebihan. Hal ini dimaksudkan untuk meningkatkan produktivitas yang dimiliki seseorang agar dapat terwujud derajat kesehatan dan kebugaran jasmani yang sesuai harapan. ${ }^{8}$ Kebugaran jasmani memiliki lima komponen dasar yaitu daya tahan jantung dan paru, kekuatan otot, daya tahan otot, kelenturan serta komposisi tubuh. Ada beberapa faktor yang mempengaruhi kebugaran jasmani yaitu genetik (keturunan), umur, jenis kelamin, latihan, kebiasaan merokok dan status gizi. Kebugaran daya tahan jantung dan paru dideûnisikan sebagai kapasitas maksimal jantung dan paru-paru untuk menghirup dan menyebarkan oksigen atau disingkat VO2 Maks. Semakin tinggi VO2 Maks maka ketahanan tubuh saat berolahraga juga semakin tinggi yang berarti seseorang yang memiliki tingkat VO2 Maks tinggi tidak akan cepat lelah setelah melakukan berbagai aktivitas. ${ }^{9}$

Seorang atlet sangat penting untuk memiliki tingkat VO2 Maks yang tinggi. Seorang atlet dengan VO2 Maks yang kurang dari 50\% tidak cukup cepat untuk melakukan aktivitas latihan yang lebih intensif karena sumber energi yang digunakan berasal dari pembakaran lemak. VO2 Maks yang kurang dari $50 \%$ akan membuat tubuh bekerja secara aerob, sehingga lemak merupakan sumber energi utama. Tubuh olahragawan atau atlet harus memiliki cadangan energi yang cukup agar dapat dimobilisasikan untuk menghasilkan energi. Cadangan energi yang berupa glikogen akan disimpan dalam otot dan hati, apabila cadangan glikogen dalam tubuh atlet sedikit maka atlet tersebut akan mudah lelah karena kehabisan tenaga. ${ }^{10}$

Berdasarkan uraian di atas, ditambah dengan pengukuran tingkat daya tahan jantung paru (VO2 Maks) pada atlet sepak bola PPLP Pekanbaru dengan metode lari 12 menit belum pernah dilakukan, maka peneliti tertarik melakukan penelitian mengenai tes pengukuran tingkat daya tahan jantung paru (VO2 Maks) pada atlet sepakbola PPLP Pekanbaru dengan metode lari 12 menit.

\section{METODE}

Penelitian ini merupakan penelitian deskriptif observasional dengan pendekatan cross sectional. Penelitian ini dilakukan di Pusat Pendidikan dan Latihan Pelajar (PPLP) Pekanbaru pada bulan September 2018 - Januari 2019. Populasi penelitian adalah seluruh atlet sepak bola di PPLP Pekanbaru. Sampel penelitian ini adalah seluruh atlet sepak bola (total sampling) dengan kriteria Drop Out yaitu atlet sedang mengalami cedera dan atlet yang sedang sakit. Daya tahan jantung paru (VO2 Maks) didapatkan menggunakan metode lari 12 menit. ${ }^{8}$

Setelah mendapatkan data yang diperlukan, data tersebut dimasukkan pada lembar kerja penelitian. Data disajikan dalam bentuk tabel distribusi frekuensi dengan analisis univariat. 
HASIL

Tabel 1. Karakteristik responden penelitian

\begin{tabular}{lll}
\hline Karakteristik & $\begin{array}{l}\text { Frekuensi } \\
(\mathbf{N})\end{array}$ & Persentase (\%) \\
\hline Usia & 0 & 0 \\
12 tahun & 1 & 4,2 \\
13 tahun & 3 & 12,5 \\
14 tahun & 9 & 37,5 \\
15 tahun & 8 & 33,3 \\
16 tahun & 3 & 12,5 \\
17 tahun & $\mathbf{2 4}$ & $\mathbf{1 0 0}$ \\
Jumlah & & \\
Lama Berlatih & 15 & 62,5 \\
$<1$ tahun & 5 & 20,8 \\
$1-<2$ tahun & 3 & 12,5 \\
$2-<3$ tahun & 1 & 4,2 \\
$3-<4$ tahun & 0 & 0 \\
$4-<5$ tahun & 0 & 0 \\
$5-<6$ tahun & $\mathbf{2 4}$ & $\mathbf{1 0 0}$ \\
\hline Jumlah & & 16,7 \\
\hline Status Gizi & 4 & 70,8 \\
Underweight $=<18.5$ & 17 & 8,3 \\
Normal $=18.5-22.9$ & 2 & 4,2 \\
Overweight $=23.0-24.9$ & 1 & 0 \\
Obesitas I $=25.0-29.9$ & 0 & $\mathbf{1 0 0}$ \\
Obesitas II $=>30.0$ & $\mathbf{2 4}$ & \\
\hline Jumlah & & \\
\hline & & 0
\end{tabular}

Berdasarkan tabel 1, responden penelitian berdasarkan usia terbanyak adalah 15 tahun (37,5\%) dan usia paling sedikit adalah 13 tahun $(4,2 \%)$. Berdasarkan lama berlatih didapatkan yang terbanyak adalah yang berlatih selama $<1$ tahun
(62,5\%) dan paling sedikit adalah yang berlatih selama $3-<4$ tahun (4,2\%). Berdasarkan status gizi didapatkan hasil yang terbanyak adalah normal $(70,8 \%)$ dan yang paling sedikit adalah obesitas (4,2\%).

Tabel 2. Hasil tes lari 12 menit

\begin{tabular}{lll}
\hline VO2 Maks & $\begin{array}{l}\text { Frekuensi } \\
(\mathbf{N})\end{array}$ & Persentase (\%) \\
\hline Baik sekali & 1 & 4,2 \\
Baik & 6 & 25 \\
Cukup & 17 & 70,8 \\
Kurang & 0 & 0 \\
Kurang sekali & 0 & 0 \\
\hline Jumlah & $\mathbf{2 4}$ & $\mathbf{1 0 0}$ \\
\hline
\end{tabular}


Berdasarkan tabel 2 didapatkan nilai VO2 Maks terbanyak adalah cukup (skor 3) dengan frekuensi 17 (70,8\%) dan yang paling sedikit adalah baik sekali (skor 5) dengan frekuensi $1(4,2)$.

Tabel 3. Distribusi gambaran tingkat daya tahan jantung paru (Vo2 Maks) berdasarkan lama berlatih

\begin{tabular}{lllllll}
\hline \multicolumn{7}{c}{ Vo2 Maks } \\
\hline $\begin{array}{l}\text { Lama } \\
\text { berlatih } \\
\text { (tahun) }\end{array}$ & $\begin{array}{l}\text { Baik } \\
\text { Sekali }\end{array}$ & Baik & Cukup & Kurang & $\begin{array}{l}\text { Kurang } \\
\text { sekali }\end{array}$ & Total \\
\hline$<1$ & 0 & 0 & 15 & 0 & 0 & 15 \\
$1-<2$ & 1 & 3 & 1 & 0 & 0 & 5 \\
$2-<3$ & 0 & 2 & 1 & 0 & 0 & 3 \\
$3-<4$ & 0 & 1 & 0 & 0 & 0 & 1 \\
$4-<5$ & 0 & 0 & 0 & 0 & 0 & 0 \\
$5-<6$ & 0 & 0 & 0 & 0 & 0 & 0 \\
\hline Total & $\mathbf{1}$ & $\mathbf{6}$ & $\mathbf{1 7}$ & $\mathbf{0}$ & $\mathbf{0}$ & $\mathbf{2 4}$ \\
\hline
\end{tabular}

Berdasarkan tabel 3 didapatkan nilai VO2 Maks baik sekali dengan frekuensi 1 orang di rentang lama berlatih $1-<2$ tahun. Nilai Vo2 Maks baik dengan frekuensi 3 orang di rentang lama berlatih 1 $-<2$ tahun, 2 orang di rentang lama berlatih $2-<3$ tahun dan 1 orang di rentang lama berlatih $3-<4$ tahun. Nilai Vo2 Maks cukup dengan frekuensi 15 orang di rentang lama berlatih $<1$ tahun, 1 orang di rentang lama berlatih $1-<2$ tahun dan 1 orang di rentang lama berlatih $2-<3$ tahun. Tidak terdapat nilai $\mathrm{VO}_{2}$ maks kurang maupun kurang sekali pada tiap rentang lama berlatih.

\section{PEMBAHASAN}

Berdasarkan tabel 1, penelitian yang dilakukan didapatkan rentang usia para atlet sepakbola Pusat Pendidikan dan Latihan Pelajar (PPLP) Pekanbaru yaitu usia 13-17 tahun dengan usia terbanyak adalah usia 15 tahun (37,5\%) dan paling sedikit adalah usia 13 tahun (4,2\%). Rentang usia ini merupakan salah satu rentang usia yang sangat bagus untuk dilakukan pembinaan.

Dalam pembinaan sepakbola yang ditempuh melalui jalur pendidikan digolongkan pada tiga tahapan, tahap pertama adalah pembinaan multilateral yang dilaksanakan pada usia $10-12$ tahun, tahap pembinaan berikutnya adalah pembinaan menengah yang dilaksanakan pada usia 13 - 17 tahun dan tahap pembinaan prestasi puncaknya adalah usia $18-24$ tahun. ${ }^{11}$
Data yang didapatkan oleh peneliti menunjukkan atlet sepakbola PPLP Pekanbaru berada pada pembinaan atlet usia menengah dan termasuk rentang usia yang bagus untuk dilakukan pembinaan. Penelitian lain yang juga mendapatkan atlet dengan rentang usia menengah adalah penelitian yang dilakukan oleh Tang pada tahun 2014 yang dilakukan terhadap atlet sepakbola Pusat Pendidikan dan Latihan Pelajar (PPLP) Sulawesi Selatan dan didapatkan hasil usia terbanyak yaitu usia 16 tahun dengan frekuensi 6 orang atlet (31,6\%) dari total 17 atlet. ${ }^{12}$ Waktu berlatih atau pembinaan atlet di PPLP paling lama selama 6 tahun, kemudian atlet akan meneruskan latihan atau pembinaannya ke Pusat Pendidikan dan Latihan Mahasiswa (PPLM).

Pada penelitian ini didapatkan lama berlatih para atlet sepakbola PPLP Pekanbaru memiliki waktu paling lama yaitu $3-<4$ tahun dengan lama berlatih terbanyak yaitu $<1$ tahun (62,5\%) dan lama berlatih paling sedikit yaitu $3-<4$ tahun (4,2\%). Lama berlatih terbanyak $<1$ tahun menunjukkan banyaknya atletatlet sepakbola yang baru bergabung dalam binaan PPLP Pekanbaru. Hal ini merupakan persiapan awal mendasar untuk keberhasilan pembinaan jalur PPLP yang mempunyai tenggang waktu pelatihan maksimal 6 tahun dalam mencapai prestasi.

Untuk mencapai suatu prestasi, sesuai dengan sistem pembinaan olahraga dari Kantor Menteri Pemuda dan Olahraga yang tersusun dalam himpunan kebijaksanaan pemerintah di bidang keolahragaan salah satu poin menyatakan bahwa 
untuk mencapai prestasi puncak dalam olahraga diperlukan latihan jangka panjang kurang lebih 8 10 tahun yang dilakukan secara kontiniu, bertahap, meningkat dan berkesinambungan. Dalam proses pentahapan pembinaan terbagi dalam 4 tahapan yaitu : 1) tahap latihan persiapan yang lamanya latihan kurang lebih $3-4$ tahun, 2) tahap latihan pembentukan $2-3$ tahun, 3) tahap latihan pemantapan 2 - 3 tahun, 4) golden age untuk sepakbola pada usia $24-30$ tahun. ${ }^{11}$ Namun dalam hal ini para atlet hanya bisa bergabung dan berlatih bersama PPLP selama 6 tahun, kemudian dalam usia emasnya dibina pada PPLM. Selain waktu lama berlatih, status gizi para atlet juga perlu diperhatikan untuk mendapatkan kebugaran yang baik dalam mengikuti latihan ataupun pertandingan.

Perhitungan status gizi yang dilakukan pada atlet sepakbola PPLP Pekanbaru mendapatkan hasil status gizi terbanyak adalah normal (70,8\%). Status gizi normal menunjukkan bahwa seorang atlet memang seharusnya memiliki status gizi yang ideal (normal) tidak terlalu kurus dan tidak terlalu gemuk. Seseorang yang memiliki lemak berlebih pada tubuhnya akan mengkonsumsi oksigen lebih rendah dibandingkan dengan seseorang yang memiliki tubuh atletis dan tidak berlemak banyak, setiap kenaikan IMT sebesar $1 \mathrm{~kg} / \mathrm{m} 2$ di ikuti dengan penurunan VO2 maks sebesar $1,30 \mathrm{ml} / \mathrm{kgBB} / \mathrm{menit}$. Atlet yang mempunyai Indeks Massa Tubuh (IMT) normal akan mempunyai tingkat VO2 maks yang baik untuk menunjang performa saat latihan maupun bertanding. ${ }^{13}$ Penelitian lain yang juga didapatkan hasil status gizi normal para atlet adalah penelitian yang dilakukan oleh Hudriah pada tahun 2018 yang dilakukan terhadap atlet sepakbola Pusat Pendidikan dan Latihan Pelajar (PPLP) Sulawesi Selatan didapatkan hasil status gizi terbanyak yaitu status gizi normal (100\%) dari total 29 orang atlet. ${ }^{14}$

Berdasarkan tabel 2, penelitian yang dilakukan didapatkan nilai daya tahan jantung paru (VO2 Maks) terbanyak adalah cukup sebanyak 17 orang atlet (70,8\%). Hasil ini menunjukkan bahwa ratarata atlet sepakbola PPLP Pekanbaru masih memiliki tingkat daya tahan jantung paru (VO2 Maks) yang cukup, masih sangat sedikit atlet yang mencapai tingkat daya tahan jantung paru (VO2 Maks) baik maupun baik sekali. Seorang atlet sangat penting untuk memiliki tingkat VO2 Maks yang tinggi.
Semakin tinggi VO2 Maks seorang atlet maka ketahanan tubuh atlet tersebut saat berolahraga juga semakin tinggi yang berarti seorang atlet yang memiliki tingkat VO2 Maks tinggi tidak akan cepat lelah setelah melakukan berbagai aktivitas. ${ }^{9}$ Seorang atlet dengan VO2 Maks yang kurang dari 50\% tidak cukup cepat untuk melakukan aktivitas latihan yang lebih intensif karena sumber energi yang digunakan berasal dari pembakaran lemak. ${ }^{10}$

Berdasarkan tabel 3, hasil pendistribusian tingkat daya tahan jantung paru berdasarkan lama berlatih didapatkan bahwa semua atlet yang waktu lama berlatihnya $<1$ tahun memiliki nilai VO2 Maks cukup, tidak ada atlet dengan waktu lama berlatih $<1$ tahun memiliki nilai VO2 Maks baik sekali maupun baik. Atlet dengan waktu lama berlatih 1 $<2$ tahun rata-rata memiliki nilai VO2 Maks baik, hanya ada satu orang atlet yang memiliki nilai VO2 Maks baik sekali dan satu orang atlet yang memiliki nilai VO2 Maks cukup. Para atlet dengan lama berlatih $2-<3$ tahun rata-rata memiliki nilai VO2 Maks baik, tidak ada atlet yang memiliki nilai VO2 Maks baik sekali, dan hanya ada satu orang atlet yang memiliki nilai VO2 Maks cukup. Lama berlatih termasuk salah satu faktor yang dapat menentukan peningkatan kadar VO2 Maks seseorang, karena pada dasarnya untuk meningkatkan nilai VO2 Maks seseorang memerlukan jenis latihan daya tahan. Latihan daya tahan ini memerlukan waktu yang lama untuk dapat terlihat hasilnya, semakin lama seorang atlet berlatih maka semakin bagus pula tingkat VO2 Maks nya. ${ }^{15}$

\section{SIMPULAN}

Berdasarkan penelitian yang telah peneliti lakukan dapat diambil kesimpulan, atlet sepakbola PPLP Pekanbaru terbanyak berusia 15 tahun (37,5\%), dan yang paling sedikit adalah usia 13 tahun $(4,2 \%)$, lama berlatih sebagian besar adalah $<1$ tahun (62,5\%), dan lama berlatih terlama yaitu 3 - $<4$ tahun (4,2\%), dan status gizi sebagian besar adalah normal (70,8\%), selebihnya tergolong dalam underweight, overweight dan obesitas (29,2\%). Tingkat VO2 Maks terbanyak atlet sepakbola PPLP Pekanbaru adalah cukup (70,8\%) dan hanya ada 1 orang atlet (4,2\%) yang memiliki tingkat VO2 Maks baik sekali. Tingkat VO2 Maks baik sekali terdapat pada atlet dengan lama berlatih $1-<2$ tahun. Tingkat VO2 
Maks baik terbanyak terdapat pada atlet dengan lama berlatih $1-<2$ tahun. Tingkat VO2 Maks cukup terbanyak terdapat pada atlet dengan lama berlatih $<1$ tahun sebanyak 15 orang atlet.

\section{DAFTAR PUSTAKA}

1. Kemenpora. Prestasi dan cabang olahraga unggulan PPLP. Jakarta: Kementerian Pemuda dan Olahraga Republik Indonesia; 2014.

2. Walid A. Meningkatkan keterampilan menggiring bola melalui metode bermain dalam kelompok kecil siswa SD Guntarano pada permainan sepakbola mini. E-JTPEHR. 2013; 1(3): 1-15.

3. Pengurus Pusat Special Olympics Indonesia. Buku panduan cabang olahraga sepak bola special olyoics. Jakarta: Special Olympics Indonesia; 2009.

4. Saputra I, Siregar AT. Upaya meningkatkan kemampuan menahan bola long pass menggunakan kaki bagian dalam siswa pada permainan sepakbola dengan metode penemuan terbimbing di kelas VIII SMP Negeri 2 Stabat T.P. 2014/2015. Jurnal Ilmu Keolahragaan. 2016; 15(1): 67-76.

5. Doni. Tingkat kesegaran jasmani anggota sekolah sepakbola U-15 tahun 2013 Desa Talagening Kecamatan Bobotsari Kabupaten Purbalingga [skripsi]. Yogyakarta: UNY; 2013

6. Bryantara OF. Faktor yang berhubungan dengan kebugaran jasmani (VO2maks) atlet sepakbola. Jurnal Berkala Epidemiologi. 2016; 4(2): 237-249.

7. Ciptadi ZD. Status kebugaran jasmani dan keterampilan bermain sepakbola siswa SSB Gama usia 13-14 tahun [skripsi]. Yogyakarta: UNY; 2013.
8. Depkes RI. Petunjuk teknis pengukuran kebugaran jasmani. Jakarta: Direktorat Jenderal Bina Kesehatan Masyarakat Direktorat Kesehatan Komunitas; 2005.

9. Sugiarto. Hubungan asupan energi, protein, dan konsumsi suplemen dengan tingkat kebugaran. Semarang. Media Ilmu Keolahragaan Indonesia. 2012; 2(2): 94-5.

10. Moehji S. Ilmu gizi 2: Penanggulangan gizi buruk. Jakarta: Medik Indonesia; 2003.

11. Widodo S. Manajemen pembinaan sepakbola pada pusat pendidikan dan latihan pelajar (PPLP) Jawa Tengah di Salatiga [tesis]. Semarang: UNES; 2005.

12. Tang A. Gambaran tingkat keseimbangan atlet sepakbola Pusat Pendidikan dan Latihan Olahraga Pelajar Sulawesi Selatan. Jurnal Ilmiah Kesehatan Diagnosis. 2014; 5(1): 122-8.

13.Pratama AWP. Hubungan status gizi dan status hidrasi terhadap VO2Max pada atlet sepakbola Beringin Putra Football Club Wonosobo [Skripsi]. Yogyakarta: Universitas Negeri Yogyakarta; 2018.

14.Hudriah E. Pengaruh latihan kondisi fisik terhadap kelincahan (agility) olahraga permainan di Pusat Pendidikan dan Pelatihan Olahraga Pelajar (PPLP) Provinsi Sulawesi Selatan [Skripsi]. Makassar: Universitas Hasanuddin; 2018.

15.Sanjaya AA. Perbedaan kapasitas VO2 maksimum antara pemain depan, tengah dan belakang anggota forum komunikasi antar sekolah sepakbola usia 17 Kabupaten Cilacap tahun 2015 [skripsi]. Yogyakarta: UNY; 2015. 